that our contribution before many months are past will be of the first order of importance; for I know I am speaking for my fellow-workers in the National Defense Research Committee when I say that nothing would give us more satisfaction than to feel that through our work we had contributed directly to the effectiveness of the war effort. Our eagerness to help can scarcely be over-estimated; may the future demonstrate that our capacities have been equal to our desires!

I cannot conclude without referring briefly to what must be to some extent in everyone's mind at this Conference-the world we are going to live in after the War is over. It is not for me to outline a world order or even to express views on Anglo-American policy. But no intelligent man who on one hand loves peace, and on the other places the highest value on individual liberty, can doubt that without some form of co-operation between our two countries no peace worth fighting for can be established. Similarly, no intelligent man who consults his head as well as his heart can fail to note great obstacles that stand in the way of effective co-operation and collaboration. It should be the duty of all trained thinkers, particularly men of science, on both sides of the water, to study these obstacles coolly and impar. tially. For only by knowing their nature may we hope to overcome them. Only by dispassionate study may we hope to reduce these barriers.

I say particularly men of science, for they realize more than many others the potentialities that lie hidden in the future. Men of science realize as many cannot the extent to which modern technology has diminished effective distances around this planet. They know; too, that the end of this revolution in transportation is not yet in sight. The world contracts before their eyes. To them dreams of new adventures and new conquests of the material universe wait for realization only on the sustained labour of free men. To-day, the men of science of Great Britain and the United States are working almost as one group with the purpose of improving instruments of war. Is it fantastic to hope that in the not too distant future the men of science of all free countries may be joined in effective action to improve, not instruments of war, but those of peace? I like to see in the present scientific liaison that runs through the centre of London, Ottawa and Washington a hopeful omen of a long period marked by the friendliest relations between the British Commonwealth of Nations and the United States. If this be so, our work foreshadows a time when professional talent in many diverse societies of free men will strive for effective co-operation to the end that we and our children may walk boldly along the paths of liberty and peace.

\section{AGRICULTURE AFTER THE WAR}

\author{
By SIR JOHN RUSSELL, F.R.S.
}

Director, Rothamsted Experimental Station

THE invention of the submarine has profoundly affected the development of British agriculture, bringing it out of its accustomed obscurity into a very high position both in the War of 1914-18 and in this War. British peace-time dietary is more varied and effective than that of any other country in Europe, but it requires so much land for its production-on the average some 1.6 acres per person-that the total area of agricultural land suffices only to provide 40 per cent of the nation's food. The remaining 60 per cent has to be imported, and it was brought in from almost all quarters of the world. This method of feeding the nation postulates peace and the smooth working of international trade, and it breaks down in war-time. Home production then becomes much more important, and the national dietary is changed so as to make less call on the land; in place of the 1.6 acres of peace-time, the aim is to get nearer to the $1 \cdot 1$ acres that suffice for the German dietary. Further, there is widespread recognition that British agriculture is a major industry, and that unless it is sufficiently prosperous to attract and retain a vigorous and intelligent body of farmers and farm workers, there will always be trouble in the country-side. Under the chastening influence of war, politicians and writers become very penitent about their past attitude to agriculture and full of good resolves for the future.

We are somewhat in this position now, and we passed through the same phase in the War of 1914-18. Then it was resolved that British agriculture really should be developed, and wages boards were set up to impose a minimum wage which would ensure the workers' efficiency and do away with the hardships which some of them had suffered. Prices were to be at such a level that these wages could be paid.

There arose the difficulty that has always proved oppressive and for which no satisfactory remedy has yet been put into operation. Agricultural produce can be raised very cheaply by peasants in almost any country in Europe and by farmers using ranching or other 'extensive' methods in some of the new countries, and trading organizations can collect it and bring it to our markets at very cheap rates. The peasant is, of course, poorly paid, but his standards are low, and the 'extensive' methods may be harmful and even destructive to the soil ; but they answer for a time. In other producing countries where sound intensive methods were used, special arrangements were often 
made on the home market so as to enable the commodity to be sold cheaply on the English market. Finally, whenever a specially bountiful harvest had provided a large excess over the usual supply, this was put on to the British market as being the only one that would take it. In consequence the prices of agricultural produce here had no relation to the cost of production on farms in Great Britain, and moreover they were quite unpredictable, so that British farmers had no idea when they sowed their crops what prices they would receive for them. The only exceptions were milk and potatoes, of which there was little or no import, and a few commodities such as high-quality meat, malting barley, seeds and certain fruits and vegetables, for which a special demand existed.

For the rank and file of the farming profession there was no security, and most farmers adopted the traditional safeguard of laying down their land to grass and cutting down all expenditure, thereby reducing the outgoings to the point at which returns, though also greatly reduced, would balance them. Farmers put up the best fight they could; they lowered costs of production by reducing the numbers of their workers but increasing the output per head from the survivors, so that finally the average output per worker was equivalent to the feeding of seventeen persons, this being higher than in any European country. Some farmers went in for considerable mechanization, but this had its disadvantages. On one farm the new system reduced the cost of wheat-growing by nearly half. But while on the old system the farm had produced 630 cwt. of meat per annum, on on the new one it produced none. Much more serious: on the old system forty men had been regularly employed, on the new one only four were needed and the remaining thirty-six were 'released': and of these, twenty-two became a charge on public funds. Obviously one-sided arrangements of this sort are not desirable. The fall in area of arable land became so serious that steps had to be taken against it : these were in the nature of contracts, and unfortunately were called subsidies.

All history shows that British agriculture cannot stand up against the unrestricted imports of foodstuffs at low prices, and if farmers are left to solve the problem unaided no better way has yet been found than lowering the level of agricultural operations. It can safely be assumed that this same difficulty will arise after the present war, and that the same method of coping with it will be adopted unless a better one has in the meantime been adopted.

Fortunately a number of people are trying to design alternative solutions. During the War of 1914-18 it was thought that small holdings would solve the problem: the small man, it was said, would work with greater economy and be content with less reward than the large farmer and so might survive. But he did not, and although many small holdings were set up, an even larger number closed down, so that this solution does not appear to be general. Clearly some new proposal is now needed, and Sir Daniel Hall supplies this in his latest book*. He advocates large units, which would mean so much regrouping of the land, alterations of buildings and redistribution of implements and stock that the present landowners could not possibly undertake the task. He therefore suggests that the State should purchase the whole of the agricultural land of the country, that a commission should cut it up into units of suitable size, provide appropriate buildings and carry out the reclamations necessary, then hand the finished farms over to the Commissioners of Crown Lands, who would pass them on to land agents, who would let them to farmers. The proposal will certainly receive the serious consideration which Sir Daniel's distinguished authority requires.

An important reason for the failure of the promised development of agriculture after the War of 1914-18 was that no decision was ever reached as to the part that agriculture should play in the national life.

The prime need in any agricultural policy is to decide what proportion of our different foods we should aim at producing; and from what countries and in what amounts we should draw the foods that we propose to import. As the largest buyers of agricultural produce in the world, we are in a position to exert a very potent influence on postwar economy in a large number of countries, and our influence will be good if we work out a proper plan and stick to it.

Whatever agricultural systems are adopted the contract price method is essential now that wages are fixed by agricultural wages boards without reference to prices of produce. When adequate prices are assured it becomes possible to decide whether we should continue the classical system in which about 50 per cent of the arable land is in grain, 25 per cent in temporary clover and grass leys, and 25 per cent in root crops and potatoes, proportions which held generally right up to the War, or whether some more intensive systems should be adopted, such as that recommended by the Astor-Rowntree group, in which farmers aim at high quality and what one might call high potential : the protective foods, milk, fruit, eggs, vegetables and high-quality meat. These gain in value by being fresh, that is, by being produced locally: they employ more people per acre and

* Reconstruction and the Land : an Approach to Farming in the National Interest. By Sir A. Daniel Hall. Pp. xi+287. (London: Macmillan and Co., Ltd., 1941.) 12s. 6d. net. 
give a larger output per acre than other kinds of produce.

Account must also be taken of the part that agriculture can play in solving social problems such as unemployment and the rehabilitation of the unfit, and also of the vitally important problem of safety in war-time.

Seience must always play an important part in agricultural development, though it needs careful management because of the wide difference in outlook between scientific workers and agriculturists. Agricultural operations are so dominated by weather and by other disturbing factors, including pests and diseases, that no rigid rules can be laid down. An experimental result can never have quite the same validity as in a chemical or physical laboratory. It may always be profoundly affected by some wholly unexpected and perhaps unobserved factor, and until it has been confirmed over a wide range of conditions it is liable to the suspicion that it may be abnormal. When all results are assembled they can be subjected to statistical analysis and an average obtained with its appropriate standard error, but it may not apply. on any particular farm even though over a hundred farms it might hold good for a majority. Frequently the farmer has arrived at a general fund of knowledge about his own farm, which he is reluctant to disturb except on very convincing evidence. 'Good husbandry' is his ideal, and he firmly believes in its 'rules', even though some of them very inadequately express the facts. The agricultural departments of the colleges necessarily reflect this attitude: farmers and students alike are usually more interested in practice than in science and so more influenced by experience than by experiments : indeed not infrequently they are prepared to ignore or at least heavily discount experimental evidence if it does not fit in with established ideas. Their outlook on Nature is usually vitalistic, and special virtue is always supposed to reside in anything of organic origin as against substances of mineral or synthetic origin.

So a difference in outlook tends to arise between the agricultural research institutes and the agricultural community they are hoping to serve, and the difierence is widened by the circumstance that the research institutes, if they are to keep their science at a serious level, have almost always to draw their staff from the science departments of the universities; usually the candidate who is otherwise most suitable has no rural background and no knowledge of agriculture; to acquire this is generally very difficult. It is necessary also to distinguish between the good research man and the good adviser, and to determine the place the adviser should have in the research institute.
Broadly speaking, the good research man can see his problem, study it in full detail and find a solution, going on with the work until he has rounded it off properly and written it up for publication. But often it is not immediately useful for practical farming, though, of course, new knowledge is bound to find its place in agricultural seience and practice. The good advisory officer can also see his problem and study it in detail; he, too, finds a solution, which may be of more immediate service on the farm than the scientific investigation. But he rarely goes beyond the stage of the interim report, so that his work is never rounded off and much of it never published, to the loss of public funds and the detriment of the juniors who also participated.

In the days when they were small, the research institutes necessarily kept close touch with the farming community and had to do both types of work: the individual members of the sta 9 knew many farmers personally and well. As agricultural science has developed and expanded, it is the advisory officer rather than the research man that has had most to do with practical farming problems. This is in part the explanation of the curious decrying of science by some agricultural writers and the elevation into prominence of some of the mystical hypotheses of plant growth and human and animal nutrition which cannot be tested scientifically. These serious problems in the relation of science to agriculture require fuller study.

\section{SCIENTIFIC CENTENARIES IN 1942}

\section{BY ENGINEER CAPTAIN EDGAR C. SMITH, O.B.E., R.N.}

GCATTERED through the coming year are days $S$ which will mark the centenaries of some of the most famous men of all time. In happier circumstances, it may be presumed that already arrangements would be in progress for the commemoration of some of these centenaries on an international scale. But more urgent tasks lie ahead. Yet it may, perhaps, be hoped that such events as the tercentenary of the death of Galileo, the tercentenary of the birth of Newton and the bicentenary of Halley will not be allowed to pass quite unnoticed. It is unnecessary to recall how the researches and discoveries of these great pioneers are closely interwoven, but it may, perhaps, be permitted to recall Rigaud's words regarding the publication of Newton's "Principia". In his essay on that immortal work Rigaud wrote: "Under the circumstances it is hardly possible to form a sufficient estimate of the immense obligation which the world owes in this respect to Halley, 